PRAISE FOR BREWING JUSTICE

"Thoroughly researched. ... Jaffee's account pulls off a difficult balancing act.” Acres USA

"Revealing." Choice

"Impassioned, systematic, and profoundly researched." Plenty

"Daniel Jaffee has done the fair-trade movement a real service in his meticulous research into the actual effect of fair trade on coffee farmers in a group of villages in Oaxaca, Mexico. Up till now the claims of fair-trade benefits for the producers have been largely based on brief visits and anecdotes, but now there is hard evidence. In analyzing the market for fair trade, he distinguishes clearly among those who wish to break the market, those who would reform the market, and those who simply want access to a growing market. But his book will be of great value not only in his conclusions about how fair trade can be made fairer, but in extending our understanding of the overwhelming power of the giant corporations in international trade, even seeking to improve their image by co-optation and dilution of the standards when faced by the challenge of fair trade."

MiCHAEL BARRATt BROWn, author of Fair Trade: Reform and Realities in the International Trading System

"It is possible to establish a global economy that is just, humane, and sustainable. But it will not be easy. The forces favoring injustice, inhumanity, and exploitation are powerful and entrenched. And, for too long, they have been supported by academics and researchers who have not bothered to examine the real costs of globalization on a standard freetrade model, let alone the real opportunities of globalization on an enlightened fair-trade model. Daniel Jaffee breaks new ground with Brewing Justice. His scholarship is stellar. His conclusions are at once realistic and inspiring. In these pages, it is possible to find the roadmap to a new and better global economy."

JOHN Nichols, The Nation

"Brewing Justice is an impressive account of the relationships and ethics embedded in fair-trade coffee. Engaging the reader in a comparative global ethnography of fair- and free-trade coffee production, the author evaluates the gains and losses of fair trade for Mexican peasants. Jaffee's 
unique accomplishment is to show the consuming public how fair trade can be realized through improving the tenuous existence of producers." philip mcmichael, author of Development and Social Change: A Global Perspective

"The idea of fair trade in a global economy is central to contemporary debates over neoliberalism, globalization, and the rule of the free market. But what are the coordinates of the fair-trade movement; what sort of alternative does it offer for producers and consumers? Daniel Jaffee is at once a fierce proponent of fair trade and a critical voice. How, he asks, can fair-trade coffee be in and against the market? With one foot in the Central American coffee fincas and the other in the intellectual world of Karl Polanyi and his disciples, Daniel Jaffee has on offer a very heady brew.” MICHAEL watTs, University of California, Berkeley

"Deepens our collective understanding of these issues as we navigate the heated debates surrounding the future of fair trade."

Stanford Social Innovation Review

"Brewing Justice is a testament to the merit of public-interest scholarly research and warrants a full recommendation to academics, activists, and policy makers alike.... Deftly interweav[es] the local experience of peasant and smallholder coffee farmers with broader discourses of international trade, social justice, and sustainability. ... An inspired and accessible look at the characters, conflicts, and contradictions at the heart of fair-trade coffee production and the larger fair-trade movement in general.” GABRiel eidelman, Natural Resources Forum

"It seems as if no factor has escaped Jaffee's consideration of the fairtrade movement. The book offers a nuanced and detailed example of the complex forces that shape poor people's livelihoods in the contemporary world. . . Delivers an incisive, yet always constructive, critique of the movement." eva villalón-Soler, Political Geography

"Jaffee's style is compassionate, comprehensive, and original. His book is highly readable and includes well-organized data that help draw a complete picture of the quality of life in Oaxacan communities. . . . Jaffee creates a deeply moving portrait of the economic and intimate realities of coffee farming and offers important glimpses into the family and cultural life of food production."

AMANDA RAPPAK, Gastronomica: The Journal of Critical Food Studies 
"By far the most comprehensive attempt yet made to quantify the benefits of fair trade."

IAN HUDSON AND MARK HUDSON, Historical Materialism

"A passionate plea for strengthening and defending fair trade, ... well grounded in sound empirical findings."

tobias Plieninger, Society \& Natural Resources

"Of the many recent books on ethical commodities, Daniel Jaffee's tome on fair-trade and sustainable coffee perhaps best captures the tension between cooperative struggles and competitive antagonisms that charges ethical agricultural networks. . . . As an academic, I find this book to be an indispensable reference with a useful mix of empirics and theoretical framing."

TAD mutersbaugh, Economic Geography

"Deserves wide readership and debate, particularly of the provocative recommendations Jaffee makes at the end. Brewing Justice is a must for anyone who believes that another world is possible."

myrna santiago, Capitalism, Nature, Socialism

"It is not often that a researcher presents a study so complete as to reveal the complexities and possibilities of a social movement without obscuring its problems, as Dan Jaffee has done in Brewing Justice." heather putnam, Cultural Geographies

"Jaffee's book does a wonderful job of spanning the global and the local." Theresa Selfa, Agriculture and Human Values 
Brewing Justice 


\title{
Brewing Justice
}

Fair Trade Coffee,

Sustainability, and Survival

\section{Daniel Jaffee}

\author{
Updated Edition
}

WITH A NEW PREFACE

AND FINAL CHAPTER

\section{甲ㅜ}

UNIVERSITY OF CALIFORNIA PRESS 
University of California Press, one of the most distinguished university presses in the United States, enriches lives around the world by advancing scholarship in the humanities, social sciences, and natural sciences. Its activities are supported by the UC Press Foundation and by philanthropic contributions from individuals and institutions. For more information, visit www.ucpress.edu.

All photographs by Daniel Jaffee.

University of California Press

Oakland, California

(C) 2007, 20I 4 by The Regents of the University of California

ISBN 978-0-520-28224-7 (paper)

ISBN 978-0-520-95788-6 (ebook)

The Library of Congress has cataloged an earlier edition of this book as follows:

Library of Congress Cataloging-in-Publication Data Jaffee, Daniel.

Brewing justice : fair trade coffee, sustainability, and survival / Daniel Jaffee.

p. $\mathrm{cm}$.

Includes bibliographical references and index. ISBN 978-0-520-24958-5 (cloth : alk. paper) ISBN 978-0-520-24959-2 (pbk. : alk. paper)

I. Coffee industry-Developing countries.

2. Exports-Developing countries.

3. Competition, Unfair. 4. Coffee-PricesDeveloping countries. I. Title.

HD9I99.D442J34 2007

$382^{\prime} .4 \mathrm{I} 37309 \mathrm{I} 724-\mathrm{dc22} \quad 200602 \mathrm{I} 880$

Manufactured in the United States of America

$\begin{array}{llllllllll}23 & 22 & 2 \mathrm{I} & 20 & \text { I9 } & \text { I } 8 & \text { I7 } & \text { I6 } & \text { I5 } & \text { I4 }\end{array}$

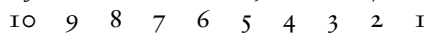

In keeping with a commitment to support environmentally responsible and sustainable printing practices, UC Press has printed this book on Natures Natural, a fiber that contains $30 \%$ post-consumer waste and meets the minimum requirements of ANSI/NISO Z39.48-I992 (R I997)

(Permanence of Paper). 
To my mother, Iris Jaffee With love and gratitude 